\title{
THE ICRC IN ACTION
}

This is the general theme of the second quarterly review, 1965, The Red Cross World (vol. XLV, No. 2, 1965) published by the League. This issue is devoted entirely to action in the field by the International Committee of the Red Cross in defence of humanity amidst the throes of war.

This illustrated world publication gives a report on an interview with Mr. Samuel A. Gonard, President of the ICRC. In reply to one of the questions put to him, "What do you see emerging as the principal tasks and opportunities for the work of the ICRC in Africa?", he replied :

"The ICRC is concerned about Africa in view of the threat of conflicts and disorders hanging over this continent. Above all we hope to see a return to peace and justice. However, we shall perhaps have to play our role of neutral intermediary yet again and must therefore make Africans understand the true nature of our humanitarian task. Yet I am certain that the Red Cross has many enthusiastic friends in Africa for whom our ideal of solidarity corresponds to their deepest hopes. In this connection the ICRC greatly appreciates the remarkable work accomplished by the League in Africa, aimed at helping young National Societies with their development."

After reviewing some of the main problems confronting the ICRC today, Mr. Gonard concluded :

" Our Institution has many other problems to face, but lack of space makes it impossible to list them all. One of them, however, deserves special mention, that of defending the universality and cohesion of the International Red Cross. It is our duty to do everything in our power to keep our humanitarian movement free from political controversy ; this demands constant vigilance and a great deal of firmness." 
The next article is an interview with the Head of the ICRC's Relief Section, Mr. Ch. Ammann; he tells why men are drawn to service as delegates of the International Committee and what holds them in this difficult and often dangerous career.

Next, Mr. Pierre Gaillard, who is himself a delegate, recalls some personal experiences in the service of the ICRC in the Yemen, in Palestine, in Algeria and in other countries. In reply to the question: "How does an ICRC delegate gain the confidence of prisoners and camp commandants ?", Mr. Gaillard recalls some of the dramatic situations with which a delegate must contend in his every day work.

Mr. Léopold Boissier analyzes the steps taken by the ICRC in 1962 during his presidency, when it accepted the request of U Thant, United Nations Secretary-General, to act as intermediary in the Cuba crisis. "The Committee", he said, " considered the appeal made to it with the full approval of such States as the United States of America and the Soviet Union as a mark of confidence. This confidence, which it values highly, has led it to redouble its efforts to achieve the universality of the Red Cross movement. It was therefore not a turning point but a flowering of the work created by Henry Dunant".

Mr. J. Pictet, ICRC Director for General Affairs, examines some of the future problems relating to the Geneva Conventions and the Red Cross in general. In connection with the protection of civilians, Mr. Pictet said : "The development of modern weapons, the more total character of war and the amazing discoveries in the field of nuclear physics have hung grave threats over civilian populations, which the Geneva Conventions leave unprotected against such dangers. Despite the enormous advances in the techniques of war, the legal rules governing the use of weapons date back to $1907 .$. and the first aerial bombardment took place in 1911. This is of course absurd. The ICRC has not given up hope of seeing States reach agreement one day on certain rules limiting the dangers incurred by civilians due to modern methods of warfare. 


\section{IN THE RED CROSS WORLD}

This again is a very difficult undertaking for it represents no less than an attack on war itself."

The review concludes with " a letter to a young ICRC delegate" by Mr. Pierre Boissier, in which he describes in what circumstances the young delegate will carry out the task entrusted to him, the difficulties with which he must contend and the satisfaction which will be his when he achieves something for the benefit of war victims. The text of the letter is as follows :

Dear Friend,

Here you are, crammed with knowledge. You have studied the four Geneva Conventions: 429 articles in all. You have been duly briefed on the principles of the Red Cross and its organisation (horribly complicated). For some months now, I have passed you in our redcarpeted corridors, looking very serious, with files under your arm.

And now man's folly has taken the upper hand again: a conflict has just broken out. Our directors, of course, are discussing it on their Mount Olympus and the man responsible for that particular geographical area has started to miss his six o'clock bus. But for you, as for most of us, it was still only an item of news in the papers.

From one moment to the next, it became your personal problem. You have been chosen to go, accompanying an experienced delegate. The time has come for your first mission.

You know a lot... and you known nothing.

As a Swiss you know nothing of war. You will meet it at close quarters. Will you like it? Perhaps, like many of those who wage it. You have never seen a people or a town fomented by passion, swept along on a tide of emotion, roused by adventure...

But, above all, like Dunant at Castiglione, you will see the sombre side of war. You will see the wounded, the dead, and worse, the stinking 
dead. It could be that, after negotiating a brief and fragile suspension of the fighting, you will be the first to venture between the lines to get to the wounded. Quite a number of your colleagues have done it before you, sometimes dodging bullets. And because you are no fool you will discover fear, an icy grip in the pit of your stomach.

You will penetrate into strange worlds. To begin with the prisonerof-war camps. You will visit them thoroughly: dormitories, kitchens, refectories, infirmaries, washing and lavatory facilities. You will speak to the prisoners, without witnesses. Sometimes this takes several days. Interviews with the prisoners' representative and the camp commander could be tricky, for tension sometimes runs high. Your presence in this barbed-wire enclosure must signify to the prisoners that they are not forgotten and that the Red Cross has the power to reach them wherever they may be. It will be up to you to give the armband that you will wear on your left arm all its symbolic meaning.

Even stranger is the world of the prison; the prison with its smell of urine, cabbage, sreeat and disinfectant; the prison with its sinister silence of anguish and waiting, broken only by the slamming of locks and the dragging footsteps of slow-moving and hopeless fatigue parties. You will see grey men, and, in their cells, those condemned to death, and the chains and the handcuffs and tangibly present, although invisible, the gallows or the firing squad.

Here, where speech is rare, the words you choose will have more weight, more value, more importance than anywhere else. Choose them well.

Actually you asked for my advice. This is the advice I received myself from an older delegate.

You will spend your time in obtaining: obtaining access to such and such a place, obtaining free passage for relief supplies, obtaining the release or exchange of prisoners.

Before you approach the person on whom the decision depends, always ask yourself this : what have I to offer him? You will almost always find something, even if it is only the fact that the Committee also looks after the war victims of his own side. Start with that, not 


\section{IN THE RED CROSS WORLD}

with the idea of bargaining, but to establish your mission, which is to be the spokesman of all those crushed by war. You will see that the doors will open. And you will call that the Red Cross miracle.

So good-by, dear Friend, and good luck!

P. Boissier.

\section{WORLD RED CROSS DAY}

No Frontiers for Red Cross has been chosen as the theme for the next World Red Cross Day which will take place on May 8, 1966. World-wide focus will be on the Red Cross Principle of Universality.

The truly distinctive character of Red Cross is that it has achieved in a practical manner the universality which no other movement has been able to attain.

Today our world is enveloped in a Red Cross network so interlaced and interrelated that no country, indeed no man, lies outside its reach or influence. The potential of this organisational structure is challenging to the imagination.

The Red Cross principle of Universality is simply but unmistakeably stated : "The Red Cross is a world-wide institution in which all Societies have equal status and share equal responsibilities and duties in helping each other."

It is encouraging to note that today Red Cross people look beyond the boundaries of their communities, even of their countries, to help as they can others in distant lands whom they will probably never know or even see. 